\title{
POLA KOMUNIKASI TRAINER DENGAN ANAK TULI DALAM MENINGKATKAN KEMAMPUAN BERKOMUNIKASI DI GRESIK
}

\author{
Ismail Hasan \\ Universitas Islam Negeri Sunan Ampel Surabaya \\ ismailhasan28@gmail.com
}

\begin{tabular}{l}
\hline Article Info \\
\hline Article history: \\
Received 20 Februari 2020 \\
Accepted 16 Maret 2020 \\
Published 10 April 2020 \\
\hline
\end{tabular}

Keyword:

Pola Komunikasi

Interpersonal, Resource

Centre, Anak Tuli

\begin{abstract}
The problem examined by this study is how the interpersonal communication patterns between trainers and deaf children in the technical implementation unit (UPT) resource center for children with special needs (ABK) in Gresik Regency, East Java Province. The aim of this research is to describe the interpersonal communication patterns between trainers and deaf children in improving their communication skills. This research uses a qualitative approach with descriptive methods.

The results of this study indicate that the interpersonal communication patterns carried out by the UPT to ABK are circular communication patterns and primary communication patterns. Early in the process before the implementation of therapy, a holistic approach is carried out on children. The form of learning at the resource center is therapy. To improve language and speaking skills, the therapy is speech therapy. The form of teaching uses Audio Verbal Teraphy.
\end{abstract}

Masalah yang dikaji dalam penelitian ini adalah bagaimana pola komunikasi interpersonal antara trainer dan anak tuli di unit pelaksana teknis (UPT) resource centre bagi anak berkebutuhan khusus (ABK) di Kabupeten Gresik Provinsi Jawa Timur. Tujuan dari penelitian adalah menjabarkan pola-pola komunikasi interpersonal antara trainer dan anak tuli dalam peningkatan kemampuan berkomunikasinya. Penelitian ini menggunakan pendekatan kualitatif dengan metode deskriptif.

Hasil penelitian ini menunjukkan, bahwa pola komunikasi interpersonal yang dilakukan oleh UPT pada ABK adalah pola komunikasi sirkular dan pola komunikasi primer. Awal proses sebelum pelaksanaan terapi, pendekatan holistik dilakukan terhadap anak. Bentuk pembelajarannya di resource centre adalah terapi. Untuk meningkatkan kemampuan berbahasa dan berbicara, terapi yang dilakukan adalah terapi wicara. Bentuk pengajarannya menggunakan Audio Verbal Teraphy.

Copyright () 2020 Jurnal Ilmu Komunikasi

\section{Editorial Office:}

Program Studi Ilmu Komunikasi, Fakultas Dakwah dan Komunikasi, UIN Sunan Ampel Surabaya. Jl. Ahmad Yani 117 Surabaya, Jawa Timur, Indonesia.

Email: jurnalilkom@uinsby.ac.id 
Jurnal Ilmu Komunikasi

Vol. 10, No. 1, April 2020

Print ISSN 2088-981X, Online ISSN: 2723-2557

Journal hompage http://jurnalfdk.uinsby.ac.id/index.php/JIK

\section{Pendahuluan}

Kehidupan seseorang memang melekat dengan adanya komunikasi, karena komunikasi merupakan sebuah proses aktivitas dalam sistem kehidupan sosial yang menjadi hakikat dari manusia itu sendiri. Dalam aspek kehidupan seharihari manusia komunikasi bisa dilihat dari sudut mana saja, mulai saat masih kecil sampai sudah dewasa, saat membuka hari sampai menutup hari, semua hal bisa diketahui bahwa manusia membutuhkan sebuah komunikasi. Sejatinya tidak ada manusia yang bisa hidup sendirian, tanpa ada bantuan orang lainnya atau manusia lain, sebab itu sudah menjadi kodrat manusia merupakan makhluk sosial. Terlebih lagi anak-anak yang mempunyai hambatan fisik dalam dirinya, seperti hambatan dalam mendengar atau tuli.

Kebutuhan berkomunikasi manusia sudah ditampakan sejak manusia itu mulai dalam kandungan. Disarankan kepada ibuibu yang hamil agar menstimulus bayi mereka dengan, salah satunya adalah mengajak anak dalam kandungan berkomunikasi. Begitu lahir, anak mengeluarkan bahasa tanda komunikasi mereka dengan menangis. Kemudian itu meningkat dengan bahasa ocehan mereka dan pembentukan bahasa yang lebih kompleks. Perolehan bahasa untuk komunikasi ini diperoleh anak, tentunya dipengaruhi oleh stimulus orang tua dan kesempurnaan serta kematangan organ komunikasi (telinga \& mulut) manusia. Sudah pasti anak yang terlahir dengan ketidaksempurnaan seperti anak tuli akan mengalami kesulitan dalam proses perolehan bahasa dan komunikasinya. Anak tuli memiliki kelainan pendengaran, sehingga mereka mengalami hambatan dalam berkomunikasi.

Manusia penyandang cacat pada umumnya memiliki keterbatasan tertentu sesuai dengan jenis cacatnya. Begitu juga dengan tunarungu atau bisa disebut tuli, stigma yang diberikan masyarakat normal seringkali digambarkan sebagai seseorang yang tidak mandiri, menyedihkan dan lain sebagainya, sehingga terbentuk persepsi dan prasangka bahwa penyandang tunarungu itu patut dikasihani, selalu butuh perlindungan dan bantuan.

Salah satunya lembaga yang menjadi objek dari peneliti yakni UPT Recource Center ABK Gresik yang mana lembaga pusat pengembangan pendidikan anak berkebutuhan khusus khususnya di wilayah Gresik Kota. Semua murid yang ada di Recource Center ini adalah manusia yang berpotensi yang layak dikembangkan untuk mencapai keberhasilan di kehidupan sehari-hari serta kreativitas dan juga produktivitas. Seorang anak tuli dalam kesehariannya mengalami banyak kekurangan dan kelemahan karena keterbatasan pendengaran dan juga sulit untuk berbicara secara verbal, mereka membutuhkan layanan konseling guna membantunya memecahkan masalah dan membentuk konsep diri yang bagus agar mereka tumbuh menjadi pribadi yang berprilaku positif.

Anak-anak yang memiliki keterbatasan sangat membutuhkan

Editorial Office:

Program Studi Ilmu Komunikasi, Fakultas Dakwah dan Komunikasi, UIN Sunan Ampel Surabaya. Jl. Ahmad Yani 117 Surabaya, Jawa Timur, Indonesia.

Email: jurnalilkom@uinsby.ac.id 
perhatian lebih extra atau intim. kesulitan melakukan komunikasi entah itu Pembelajaran untuk anak tuli membutuhkan suatu pola tersendiri sesuai dengan kebutuhannya masing-masing, yang berbeda antara satu dengan yang lainnya. Dalam penyusunan program pembelajarannya, setiap trainer atau terapis sudah memiliki catatan atau data pribadi setiap peserta didiknya atau pasiennya. Data pribadi bisa berkaitan dengan karakter spesifik, kemampuan serta kelemahannya, kompetensi yang dimiliki serta kemajuan perkembangannya.

Unit Pelayanan Terpadu Resource Centre ABK Gresik memiliki tugas serta fungsi untuk memberikan dukungan dalam sistem pendidikan, advokasi, aktualisasi diri dimanapun anak berkebutuhan khusus berada, serta mampu meningkatkan kepribadian mandiri nantinya untuk digunakan bekal selanjutnya di kehidupan sosial atau di lingkungan sekolah.

Peneliti melihat beberapa kondisi fenomena bagaimana kemampuan berkomunikasi anak-anak berkebutuhan khusus yang berada di Unit Pelayanan Terpadu Resource Centre ABK Gresik khususnya anak tuli bisa dibilang kondisinya untuk anak usia dini yang memang menjadi prioritas dalam pengajaran perkembangan bahasa serta bicaranya, lebih masuk ke dalam fase proses pengenalan kosa-kata, tata bahasa entah verbal ataupun non-verbal. Bisa dikatakan masih banyak anak yang memang belum bisa mengeluarkan kata ataupun kalimat-kalimat lebih cenderung berteriak-teriak dan menunjukkan gestur tubuh atau emosinya. Dalam realitanya sendiripun masih ada anak tuli yang verbal.

Mengenai kondisi di Unit Pelayanan Terpadu Resource Centre ABK Gresik dalam lingkup belajar mengajarnya mereka tidak mencampur semua anak-anak berkebutuhan khusus dalam satu kelas, namun mereka memisah dan membaginya sesuai tingkatan kekurangan mereka, seperti tuna rungu dengan tuna rungu, tuna netra dengan tuna netra juga. Jadi, tidak dicampur agar dalam proses interaksinya nanti bisa lebih fokus dalam belajar mengajar dengan mereka. Disini para trainernya biasa juga disebut terapis.

Fenomena-fenomena di atas, dirasa dengan adanya pola komunikasi yang digunakan dalam metode terapi para trainer dirasa bisa meningkatkan kemampuan komunikasi (berbahasa dan berbicara) mereka khususnya nanti dalam mengemban pendidikan yang mana bisa digunakan untuk masa yang akan datang.

\section{Kajian Pustaka}

\section{Pola Komunikasi}

Pola komunikasi merupakan serangkaian dua kata, karena keduanya mempunyai keterkaitan makna. Sehingga mendukung dengan makna lainnya, maka lebih jelasnya dua kata tersebut akan diuraikan tentang penjelasannya masing-masing.

Menurut Kamus Besar Bahasa Indonesia, pola berarti bentuk atau sistem, cara atau bentuk (struktur) yang tetap yang mana pola dapat dikatakan 
contoh atau cetakan. ${ }^{1}$ Pola pada dasarnya adalah sebuah gambaran tentang sebuah proses yang terjadi dalam sebuah kejadian sehingga memudahkan seseorang dalam menganalisa kejadian tersebut, dengan tujuan agar dapat meminimalisasikan segala bentuk kekurangan sehingga dapat diperbaiki.

Pola Komunikasi adalah proses atau pola hubungan yang dilakukan oleh dua orang atau lebih guna menyampaikan pesan sesuai dengan yang diinginkan. Jadi menurut Effendy yang dimaksud dengan pola komunikasi adalah proses yang dirancang untuk mewakili kenyataan keterpautannya unsur-unsur yang dicakup beserta keberlangsungannya, guna memudahkan pemikiran secara sistematik dan logis. ${ }^{2}$

Menurut Onong Uchjana Effendy dalam bukunya Ilmu, Teori Dan Filsafat Komunikasi mengemukakan bahwa ada 4 (empat) pola komunikasi (atau yang disebut dengan model komunikasi) yakni: ${ }^{3}$
a. Pola Komunikasi Linear
b. Pola Komunikasi Sirkular
c. Pola Komunikasi Primer
d. Pola Komunikasi Sekunder

\section{Komunikasi Interpersonal}

$$
\begin{gathered}
\text { Komunikasi } \\
\text { merupakan kegiatan yang sangat }
\end{gathered}
$$

1 Departemen Pendidikan Nasional, "Kamus Besar Bahasa Indonesia edisi ke-3", (Jakarta: Balai Pustaka, 2002), 885.

2 Onong Uchjana Effendy, "Dinamika Komunikasi”, (Bandung: PT. Remaja Rosdakarya, 1993), 30. dominan dalam kehidupan sehari-hari, namun tidaklah mudah memberikan definisi yang dapat diterima semua pihak.

Sebagaimana layaknya konsepkonsep dalam ilmu sosial lainnya, komunikasi interpersonal juga mempunyai banyak definisi sesuai dengan persepsi ahli-ahli komunikasi yang memberikan batasan pengertian. Trenholm dan Jensen (1995:26) medefinisikan komunikasi interpersonal sebagai komunikasi antara dua orang yang berlangsung secara tatap muka (komunikasi diadik). Sifat komunikasi ini adalah: (a) spontan dan informal; (b) saling menerima feedback secara maksimal; (c) partisipan berperan fleksibel.

Menurut Devito (1989), komunikasi interpersonal adalah penyampaian pesan oleh satu orang dan penerimaan pesan oleh orang lain atau sekelompok kecil orang, dengan berbagai dampaknya dan dengan peluang untuk memberikan umpan balik segera (Onong U. Effendy, 2003: $30){ }^{4}$

Berdasarkan asumsi ini maka dapat dikatakan bahwa dalam proses komunikasi interpersonal terdapat komponen-komponen komunikasi yang saling berperan sesuai dengan karakteristik komponen itu sendiri. ${ }^{5}$

a. Sumber/komunikator

${ }^{3}$ Effendy, Dinamika, 33

4 Aw Suranto, Komunikasi Interpersonal, (Yogyakarta: Graha Ilmu, 2011), 3-4.

${ }^{5}$ Suranto, Komunikasi, 7-9. 

b. Encoding
c. Pesan
d. Saluran
e. Penerima/komunikan
f. Decoding
g. Respon
h. Gangguan

\section{Trainer}

Trainer berasal dari bahasa inggris train yang berarti melatih, Trainer berarti Pelatih dan Training berarti Pelatihan. Trainer merupakan orang yang memberikan pelatihan berupa pengetahuan dan keterampilan.

Trainer merupakan individu yang menyampaikan materi pelatihan. Menurut kamus Cambridge (2008) trainer adalah seorang yang mengajarkan keterampilan kepada manusia untuk persiapan pekerjaan, kegiatan atau olahraga. Sedangkan kamus bahasa Indonesia (2008) menambahkan latihan, dan bimbingan. ${ }^{6}$

Kemampuan seorang trainer akan diakui bila yang bersangkutan dapat mengubah trainee (sebutan bagi individu yang diajar oleh trainer). Kompetensi trainer ada 3, yaitu (1) menjalin hubungan kerja yang baik pada situasi pembelajaran, menerapkan bimbingan yang tepat dalam situasi pembelajaran, memonitor proses pembelajaran dalam

\footnotetext{
${ }^{6}$ David Mafazi, Kompetensi Seorang

Trainer, November 2, 2019,

https://warstek.com/2018/05/23/trainer/.

${ }^{7}$ Cole Publishing Company Pramudyo,

Chrisogonus D., Cara Pinter Jadi Trainer, (Indonesia Cerdas: Yogyakarta, 2007), 12.
}

situasi pembelajaran. Biasanya trainer menangani kondisi klien yang kondisinya Zero atau netral. Sehingga tugas trainer memberikan skill dan kompetensi. $^{7}$

Dalam hal yang berhubungan dengan lembaga pendidikan bagi anakanak berkebutuhan khusus, trainer disini memiliki arti atau makna lain jika terkait dengan lembaga tersebut. Di lembaga pendidikan khusus tugas seorang trainer yakni memberikan pelatihan dan juga pengetahuan. Semisal anak tuli, dibagian ini trainer akan memberikan pelatihan berupa keterampilan berbicara dan juga pengetahuan tentang mendengar, yang memang menjadi kekurangan bagi penyandang tuli tersebut.

Dalam pelatihan diperlukan kecakapan komunikasi dari seorang trainer dari mulai kemampuan menyampaikan materi, kemampuan membangun hubungan yang kondusif dengan peserta pelatihan sampai kemampuan dalam mengatasi hambatan yang terjadi ketika pelatihan berlangsung. ${ }^{8}$

Peran Trainer yang ada dilembaga pendidikan khusus jelas harus memiliki kompetensi pedagogis (ortopedagogis), yaitu kompetensi memahami peserta didik tuli melalui serangkaian asesmen, dan kompetensi yang terkait dengan penguasaan strategi pembelajaran yang

\footnotetext{
${ }^{8}$ Kathartika Lestari, "Pola Komunikasi Efektif Trainer Pada Training Induction Karyawan Btpn Syariah", Thesis: (UNPAS Yogyakarta: 2017) : 4.
} 
berbasis bahasa dan komunikasi, sebab anak tuli masuk ke sekolah belum berbahasa dan terbatas kemampuan komunikasinya, maka tugas pembelajaran yang paling awal adalah mengembangkan kemampuan berbahasa untuk bisa berkomunikasi. Di sisi lain, trainer harus memiliki kompetensi kompensatoris, yaitu kemampuan berkomunikasi dengan tunarungu, seperti kemampuan berkomunikasi verbal dan nonverbal seperti pengembangan wicara, berisyarat dan membaca isyarat.

Dalam Kamus Besar Bahasa Indonesia kata "holisme" didefinisikan sebagai cara pendekatan terhadap suatu masalah atau gejala, dengan memandang gejala atau masalah itu sebagai suatu kesatuan yang utuh. ${ }^{9}$ Dari kata holisme itulah kata holistik diartikan sebagai cara pandang yang menyeluruh atau secara keseluruhan.

Dalam ranah pendidikan, pendidikan holistik merupakan suatu metode pendidikan yang membangun manusia secara keseluruhan dan utuh dengan mengembangkan semua potensi manusia yang mencakup potensi sosial-emosi, potensi intelektual, potensi moral atau karakter, kreatifitas, dan spiritual. Tujuan pendidikan holistik adalah untuk membentuk manusia holistik. Sedangkan manusia holistik adalah manusia yang mampu mengembangkan seluruh potensi yang

9 Departemen Pendidikan Nasional, Kamus Besar Bahasa Indonesia, (Jakarta: New Phoenix, 2002), 406. ada dalam dirinya. pendidikan holistik merupakan suatu metode pendidikan yang membangun manusia secara keseluruhan dan utuh dengan mengembangkan semua potensi yang mencakup potensi sosial-emosi, potensi intelektual, potensi moral atau karakter, kreatifitas dan spiritual. $^{10}$ Potensi yang ada dalam diri manusia meliputi potensi akademik, potensi fisik, potensi sosial, potensi kreatif, potensi emosi dan potensi spiritual.

Miller, dkk., merumuskan bahwa pendidikan holistik adalah pendidikan yang mengembangkan seluruh potensi siswa secara harmonis (terpadu dan seimbang), meliputi potensi intelektual (intellectual), emosional (emotional), fisik (physical), sosial (sosial), estetika (aesthetic), dan spiritual. Manusia yang mampu mengembangkan seluruh potensinya merupakan manusia yang holistik, yaitu manusia pembelajar sejati yang selalu menyadari bahwa dirinya adalah bagian dari sebuah sistem kehidupan yang luas, sehingga selalu ingin memberikan kontribusi positif kepada lingkungan hidupnya. ${ }^{11}$

\section{Anak Tunarungu (Tuli)}

Istilah tunarungu diambil dari kata "Tuna" dan "Rungu", Tuna artinya kurang dan Rungu artinya pendengaran. Seseorang dikatakan tunarungu apabila ia tidak mampu mendengar atau kurang mampu

10 Ratna Megawangi, Pendidikan Holistik, (Cimanggis: Indonesia Heritage Foundation, 2005), 6.

\footnotetext{
${ }^{11}$ Megawangi, Pendidikan, 8.
} 
mendengar suara. ${ }^{12}$ Anak tunarungu/ tuli merupakan salah satu bagian dari anak luar biasa yang mengalami kecacatan fisik terutama pada pendengaran. Kecacatan pendengaran bagi anak tunarungu otomatis berpengaruh langsung terhadap kemampuan berkomunikasi. Rasionya muncul karena akibat tidak mendengar maka ia kehilangan kemampuan untuk meniru bahasa ucapan orang lain atau apa yang ia dengar. Dengan demikian, perolehan bahasanya terhalang diakibatkan tidak mendengar.

Menurut Daniel F. Hallahan dan James H. Kauffman, tunarungu adalah suatu istilah umum yang menunjukkan kesulitan mendengar, yang meliputi keseluruhan kesulitan mendengar dari yang ringan sampai yang berat, digolongkan kedalam bagian tuli dan kurang dengar. Orang tuli adalah seseorang yang kehilangan kemampuan mendengar sehingga menghambat proses informasi bahasa melalui pendengaran, baik memakai ataupun tidak memakai alat bantu mendengar. Sedangkan seseorang yang kurang dengar adalah seseorang yang biasanya dengan menggunakan alat bantu dengar, sisa pendengarannya cukup memungkinkan keberhasilan proses informasi bahasa melalui pendengaran. ${ }^{13}$

12 Permanarian Somad, Ortopedagogik Anak Tunarungu (Bandung: Departemen Pendidikan dan Kebudayaan, 1995), 26.

13 Permanarian Somad, Ortopedagogik anak Tunarungu, (Bandung: Departemen Pendidikan dan Kebudayaan, 1995), 26.
Menurut Andreas Dwijosumarto, tunarungu dapat diartikan sebagai suatu keadaan kehilangan pendengaran yang mengakibatkan seseorang tidak dapat menangkap berbagai perangsang terutama melalui indera pendengaran. ${ }^{14}$

Karakteristik Anak Tuli, yakni:

a. Aspek inteligensi

Pada umumnya inteligensi anak tunarungu secara potensial sama dengan anak normal, tetapi secara fungsional perkembangannya dipengaruhi oleh tingkat kemampuan berbahasanya, keterbatasan informasi, dan daya abstraksi anak. Akibat ketunarunguannya menghambat proses pencapaian pengetahuan yang luas. ${ }^{15}$

b. Aspek bahasa dan bicara

Kemampuan berbicara dan bahasa anak tunarungu berbeda dengan anak yang mendengar disebabkan oleh perkembangan bahasa erat kaitannya dengan kemampuan mendengar.

Perkembangan bahasa dan bicara pada anak tunarungu memerlukan pembinaan secara khusus dan intensif, sesuai dengan taraf ketunarunguan dan kemampuankemampuan yang lain. Karena anak tunarungu tidak bisa mendengar bahasa, kemampuan berbahasanya tidak akan berkembang bila ia tidak

${ }^{14}$ Somad, Ortopedagogik, 27.

${ }^{15}$ Sunardi, Intervensi Dini Anak Berkebutuhan Khusus, (Jakarta: Departemen Pendidikan dan Kebudayaan, 2007), 156. 
dididik atau dilatih secara khusus. Akibat dari ketidakmampuannya dibandingkan dengan anak yang mendengar dengan usia yang sama, maka dalam perkembangan bahasanya akan jauh tertinggal.

c. Aspek emosi dan sosial

Ketunarunguan dapat mengakibatkan terasing dari pergaulan sehari-hari, yang berarti mereka terasing dari pergaulan atau aturan sosial yang berlaku dalam masyarakat dimana ia hidup. Keadaan ini menghambat perkembangan kepribadian anak menuju kedewasaan. Akibat dari ketrasingan tersebut dapat menimbulkan efek-efek negatif seperti: egosentrisme yang melebihi anak normal, mempunyai perasaaan takut akan lingkungan yang lebih luas, ketergantungan terhadap orang lain, perhatian mereka lebih sukar dialihkan, mereka umumnya memiliki sifat yang polos, sederhana dan tanpa banyak masalah, dan lebih mudah marah dan cepat tersinggung. ${ }^{16}$

\section{Peningkatan Kemampuan}

\section{berkomunikasi}

a. Kemampuan berbahasa

Bahasa adalah alat untuk berkomunikasi, mengemukakan perasaaan atau pikiran yang mengandung makna tertentu baik melalui ucapan, tulisan dan bahasa isyarat/bahasa tubuh. Setiap bahasa memiliki aturan tertentu dan komunikasi dikatakan efektif bila orang yang diajajk berkomunikasi mengerti apa yang dikemukan oleh sumber komunikasi. Kemampuan berbahasa akan berkembang sesuai dengan tahap perkembangan anak (Morgan, 1981). ${ }^{17}$

Keterampilan berbahasa dapat dikelompokkan ke dalam dua kategori, yakni aspek reseptif dan aspek produktif. Aspek reseptif bersifat penerimaan atau penyerapan, seperti yang tampak pada kegiatan menyimak dan membaca. Sementara aspek produktif bersifat pengeluaran atau pemroduksian bahasa, baik lisan maupun tertulis sebagaimana yang tampak dalam kegiatan berbicara dan menulis.

Dalam memperoleh kemampuan berbahasa biasanya kita melalui suatu hubungan urutan yang teratur: awal mulanya pada masa kecil kita belajar menyimak/ mendengar bahasa, kemudian berbicara, membaca, dan menulis. Dengan demikian, rangkaian pemerolehan keterampilan berbahasa yaitu keterampilan menyimak, berbicara, membaca, dan menulis. ${ }^{18}$ Tujuan pengajaran bahasa ialah membantu anak mengembangkan kemampuan

18 Guntur, Berbicara Sebagai, 15.

16 Somad, Ortopedagogik, 36-39.

${ }^{17}$ Henry Guntur Tarigan, Berbicara Sebagai Suatu ketrampilan Berbahas (Bandung: Angkasa, 1983), 10. 
berko munikasi baik secara lisan maupun tertulis.

b. Keterampilan berbicara

Merupakan suatu kemampuan yang dimiliki oleh setiap manusia yang berbeda-beda antara satu manusia dengan yang lainnya. Menurut kamus besar bahasa Indonesia, keterampilan berasal dari kata terampil yang artinya cakap dalam menyelesaikan tugas, mampu dan cekatan. Keterampilan adalah kegiatan yang berhubungan dengan urat syaraf dan otot-otot (neoromuscular) yang lazimnya tampak dalam kegiatan jasmaniyah seperti berbicara, menulis, mengetik, olahraga dan lain sebagainya. $^{19}$

Berdasarkan uraian di atas dapat disimpulkan bahwa keterampilan adalah suatu kecakapan, kemampuan dan ketepatan dalam menyelesaikan suatu tugas. Berbicara merupakan suatu peristiwa penyampaian maksud, gagasan, pikiran, perasaan seseorang kepada orang lain dengan menggunakan bahasa lisan, sehingga maksud tersebut dipahami oleh orang lain. Bahasa lisan adalah alat komunikasi berupa simbol yang dihasilkan oleh alat ucap manusia. Jadi berbicara adalah kemampuan mengucapkan bunyi -bunyi artikulasi atau kata untuk
${ }^{19}$ Muhibbib Syah, Psikologi Belajar, (Jakarta: PT Raja Grafindo Persada, 2007), 121. menyatakan serta menyampaikan pikiran, gagasan, dan perasaan.

Hal ini sejalan dengan pendapat Nunan (1999), yang menyimpulkan bahwa berbicara sebagai suatu kompetensi komunikatif mencakup; pengetahuan tentang tata bahasa dan kosa kata bahasa itu; (2) pengetahuan tentang kaidah kaidah berbicara (misalnya, mengetahui bagaimana caranya memulai dan mengakhiri percakapan, mengetahui topik apa saja yang dapat dibicarakan dalam berbagai tipe peristiwa tutur yang berbeda, mengetahui bentuk bentuk sapaan mana yang harus digunakan dengan orang - orang yang berbeda yang diajak berbicara seseorang dan dalam berbagai situasi yang berbeda; mengetahui bagaimana cara menggunakan dan menjawab berbagai tindak tutur seperti permohonan, permintaan maaf, terimakasih, dan ajakan; dan (4) mengetahui bagaimana cara menggunakan bahasa secara tepat.

\section{Metode Penelitian}

Metode penelitian yaitu menggunakan metode penelitian deskriftif kualitatif, dan untuk menggali data melalui observasi, dan wawancara kepada narasumber yang sudah ditentukan. Wawancara tersebut dilakukan dengan 2 narasumber utama yaitu 1 orang Kepala 
sekolah dan 1 Trainer dengan beberapa sample anak selama satu bulan yakni 16 anak dengan umur yang berbeda-beda.

Penelitian ini menggunakan teknik analisis deskriptif Miles dan Huberman yang dimana prosesnya melalui tahap awal yaitu reduksi data, penyajian data dan yang terakhir adalah penarikan kesimpulan. Data dalam penelitian ini peneliti mendeskripsikan data kemudian disimpulkan sesuai dengan teknik analisis, adapun data yang dimaksud yaitu beberapa temuan tentang pola komunikasi interpersonal antara trainer dengan anak tuli dalam meningkatkan kemampuan berkomunikasinya.

\section{Hasil dan Pembahasan}

\section{Implementasi Pola Komunikasi}

Interpersonal Antara Trainer Dengan Anak Tuli Dalam Meningkatkan Kemampuan Berkomunikasi

Dalam hal ini peneliti akan menunjukkan atau memaparkan terkait proses komunikasi interpersonal yang terjadi antara trainer dengan anak tuli di UPT Resource Centre ABK Gresik dalam proses terapi yang terjadi dalam ruang belajarnya. Mulai dari pendekatan yang dilakukan awal masuk ruang kelas sampai penanganan saat adanya gangguan atau hambatan yang terjadi saat berkomunikasi dengan mereka serta mengenai tata bahasa yang digunakan anak tuli yang memang terjadi saat proses komunikasi berlangsung.

1. Pendekatan emosional dalam proses komunikasi interpersonal antara trainer dengan anak tuli di UPT Resource Centre ABK Gresik

Pada proses awal komunikasi mereka antara trainer dengan anak tuli saat peneliti melakukan observasi yang mana menjadi sample penelitian yakni Safirah, M. Hisamudin Zein, M. Rizky A., M. Rafif Izzudin, M. Aditya Naufal A, Alvian, Zulfan Qunurul, Dirga (Alif), Arvin, Hisam, Fatim, dan Thalia Adiva (balita) serta Aurel, Uyyun, M. Izzan Danish, Tristan, Pandu (anak sudah diatas lima tahun), saat d iruangan kelas para trainer melakukan pendekatanpendekatan yang lebih terbuka dan luwes agar anak-anak tidak merasa kaku atau tertutup, terlebih pada anak yang masih balita atau masih memiliki masalah dalam emosionalnya, seperti dengan melakukan doa bersama selanjutnya menanyakan kabar mereka, lalu melakukan kegiatan apa yang anak sukai terlebih dahulu biasanya kegiatan menggambar atau mewarnai, agar nanti dalam proses pembelajaran berlangsung bisa lebih fokus.

Lewat bentuk komunikasi yang mana memang digunakan para trainer jika keadaan anak yang masih belum bisa mendengar atau masih tahap awal menggunakan komunikasi secara non-verbal atau lewat gerakan tangan menadah pertanda kalau berdoa. Intinya pendekatan awal yang terbuka atau luwes sangat dibutuhkan agar 
terciptanya komunikasi yang lebih efektif antar keduanya. Sebab di RC ini anak-anak tuli tidak semua sama dalam intelejensinya atau sifat karakternya, pasti berbeda tiap individu, ada yang memang mudah dalam menyesuaikan diri ada juga yang masih tertutup pribadinya sehingga menyulitkan dalam proses komunikasi berlangsung. Peneliti mengamati 17 orang anak yang memang ada yang masih dalam tahap awal yakni belajar mendengar dan anak yang memang sudah mampu berkomunikasi secara verbal, dan memiliki intelenjensi yang baik setelah menjalani terapi khusus di $\mathrm{RC}$.

Komunikasi interpersonal mempunyai peranan penting dalam merubah keadaan seseorang bahkan membentuk karakter atau sifat seseorang bila komunikasi tersebut berjalan efektif. Penyampaian pesan antara trainer dan murid yang merupakan anak berkebutuhan khusus bagian tuli adalah saling memberi dan menerima pesan dan obrolan bersifat dua arah dan juga bisa saling bertukar informasi.

RC ini memang lebih dikhususkan untuk terapi atau mengurangi ketidakmampuan anakanak berkebutuhan khusus. Untuk keadaannya sendiri bisa dibilang masih banyak anak-anak yang memiliki kesulitan dalam berkomunikasi/ berbahasa dan berbicara terkhusus anak tuli, namun banyak juga yang bukan anak tuli juga menderita hal serupa.

langkah awal atau pendekatan awal dalam proses pembelajaran yakni dengan berdoa, lalu menanyakan kabar mereka serta memberikan kegiatan yang mereka sukai terlebih dahulu agar bisa lebih fun atau merasa senang dalam proses pembelajaran atau terapi nantinya.

kesulitan dalam proses komunikasi interpersonal yang biasanya terjadi itu disebabkan oleh faktor psikis atau emosional seperti kepribadian atau sifat anak itu sendiri, rata-rata yang bersifat tertutup atau introvert dan masih menolak kekurangan mereka cenderung lebih rewel saat memulai proses pembelajaran berlangsung.

tata bahasa yang digunakan anak tuli yang mana sedari awal tidak menjalani terapi khusus dan juga menggunakan alat bantu dengar pasti tata bahasanya cenderung berbeda, biasanya kata perkata terbalik. Seperti kalimat yang aslinya "kamu kesini naik apa?" menjadi "kamu apa naik?" Dan sebagainya. Faktor seperti itulah yang menjadi kendala dalam proses komunikasi dengan anak tuli. Akan tetapi jika dari awal sudah mendapat penanganan khusus dan ada alat bantu dengar, hambatan tersebut bisa diatasi.

Aktivitas komunikasi interpersonal trainer dengan anak tuli dilakukan dengan cara trainer menjalin komunikasi dengan anak tersebut secara komunikatif dengan 
cara menunjukkan sikap luwes, terbuka, responsive, dan simpatik. Trainer menunjukkan sikap ramah, penuh pengertian, sabar, antusias, bersemangat dalam menyampaikan pelajarannya supaya menciptakan rasa senang anak terhadap apa yang diberikan para trainer. Trainer memotivasi anak-anak tuli dalam meningkatkan rasa percaya diri mereka, khususnya dalam aspek fisik dan sosial. Supaya mereka bisa mengikuti pembelajaran yang efektif dalam meningkatkan kemampuan berbahasa dan berbicara mereka.

2. Terapi sebagai metode pembelajaran yang digunakan trainer untuk meningkatkan kemampuan berkomunikasi (berbahasa dan berbicara) anak tuli

Dalam proses komunikasinya anak-anak tuli yang memang masih dalam tahap awal yakni belajar mendengar, seperti anak balita yang menjadi sample peneliti yakni Safirah, M. Hisamudin Zein, M. Rizky A., M. Rafif Izzudin, M. Aditya Naufal A, Alvian, Zulfan Qunurul, Dirga (Alif), Arvin, Hisam, Fatim, dan Thalia Adiva, peneliti melihat saat proses observasi ratarata anak-anak yang masih balita sama dalam proses komunikasinya, dan tujuan para trainer pasti melatih mereka agar nanti bisa memberikan respon entah itu bahasa oral ataupun lewat bentuk non-verbalnya. Bisa dikatakan proses komunikasi interpersonal antara trainer dengan anak tuli di RC ini komunikasi bersifat diadik, yakni tatap muka, sebab untuk mengajar anak-anak yang memang mengalami gangguan pendengaran pastinya menggunakan gestur tubuh, mimik muka/ ekspresi wajah sebagai komponen utama agar bisa mendapat respon yang maksimal. Selanjutnya setelah mereka sudah mampu bisa mendengar mereka akan diajari berbahasa serta berbicara.

Selanjutnya setelah itu semua berlangsung, proses berikutnya menangani hambatan atau kesulitan yang memang terjadi saat komunikasi berlangsung. Hambatan memang sering terjadi saat melakukan komunikasi terlebih lagi jika berkomunikasi dengan anak yang mengalami gangguan pendengaran. Perbedaan bahasa serta kondisi psikis atau emosional mereka menjadi gangguan yang sering terjadi. Peneliti menemukan di RC hambatannya cenderung lebih ke kepribadian atau aspek psikis para anak-anak tuli. Rata-rata yang bersifat tertutup atau introvert dan masih menolak kekurangan mereka cenderung lebih rewel saat memulai proses pembelajaran berlangsung. Itu menjadi kesulitan yang memang sering terjadi, ada anak yang saat berlangsungnya pembelajaran masih menangis atau rewel dan lain sebagainya, seperti sebagian anak yang menjadi sample peneliti yakni M. Hisamudin Zein, M. Aditya Naufal A, Hisam, dan Thalia Adiva. 
Disini para trainer memegang peranan penting dalam lancarnya arus komunikasi yang terjadi di dalam ruang terapi. Para trainer membiarkan dahulu jika mereka menangis atau rewel dan sebagainya. Setelah kondisi emosional anak-anak sudah dirasa mereda para trainer perlahan-lahan melakukan pendekatan lagi yang nantinya bisa membentuk kedekatakan yang lebih guna melancarkan proses komunikasi.

Dalam hal ini peneliti mengupas lebih jauh terkait metode atau bentuk pembelajaran yang digunakan para trainer di Resource Centre ini guna meningkatkan kemampuan berkomunikasi anak tuli meliputi peningkatan kemampuan berbahasa dan berbicara. Pertama mulai dari langkah awal atau tahap awal dalam pembelajaran seperti apa, selanjutnya metode terapi seperti apa yang digunakan para trainer, lalu kesulitan dalam proses pembelajaran berlangsung, selanjutnya rentang waktu dalam proses pengajarannya, kemudian tahapan khusus dalam terapi guna membentuk kosakata atau tatabahasa pada anak tuli yang ada di Resource Centre.

Pendekatan sebelum terapi berlangsung adalah kunci dari suksesnya bentuk pembelajaran nantinya. Yakni dengan memperhatikan kebutuhan manusia secara umum yaitu bio psycho sosial spiritual dengan pendekatan anak secara holistik. Lebih berfokus pada kondisi psikologis para anak tuli yang memang masih mengalami kesulitan atau kendala. Intinya pendekatan awalnya disesuaikan kondisi psikologis tiap-tiap anak.

Jadi ada beberapa terapi yang bisa digunakan untuk membantu ABK dalam meminimalisir atau mengurangi keterbatasan mereka bahkan bisa menyembuhkan walaupun tidak sepenuhnya hilang. Dan menurut Innik ada beebrapa kelas yang digunakan memang untuk lebih mengembangkan kemampuan anak agar lebih produktif yang nantinya bisa menimbulkan sikap yang positif, seperti kelas memasak, menjahit dan lainnya.

Jadi untuk terapi wicara di RC ini para trainer menggunakan audio verbal therapy, dimana terapi yang dilakukan pada anak yang memiliki gangguan pendengaran yang sudah memiliki alat bantu dengar. Tahaptahapannya meliputi belajar mendengar, lalu jika sudah ada respon atau feedback secara verbal baru mulai tahap mendengar setelah tahap mendengar sudah dirasa sudah meningkat pastinya mereka sudah bisa mengeluarkan bahasa atau bicara secara verbal, yang pada akhirnya bisa melakukan komunikasi selanjutnya mereka bisa melakukan aktivitas-aktivitas seperti anak pada umumnya. Untuk rentang waktu anak sudah bisa dikatakan lancar dalam berkomunikasi tidak bisa dipastikan. Sebab menyangkut kondisi psikologis mereka dan juga 
alat bantu dengar mereka sesuai atau tidak. Tapi yang paling utama yakni kondisi psikologis atau tingkatan intelejensi mereka, semakin baik kondisi psikologis dan juga tingkatan intelejensi mereka maka akan semakin cepat pula peningkatan kemampuan berkomunikasi mereka.

Untuk pengajarannya saat ini bisa dibilang terbantu dengan teknologi yang membantu para penyandang tunarungu atau tuli yakni dengan memakai alat bantu dengar, sample yang peneliti pilih memang anak yang sudah menggunakan alat bantu dengar, dengan kondisi pendengaran yang berbeda pula, tapi rata-rata masih dikatakan sedang gangguan pendengarannya. Maka dari itu Novi menggunakan terapi yang bernama Audio Verbal Therapy.

Yang dimaksud AVT yaitu pendekatan trainer/pendidik yang berpusat dan mendorong penggunaan percakapan naturalistik serta penggunaan bahasa lisan untuk berkomunikasi. AVT adalah pendekatan yang menekankan penggunaan sisa pendengaran untuk membantu anak belajar mendengarkan, memproses bahasa verbal, dan berbicara. Untuk model terapi wicara ini Audio Verbal Therapy Anak-anak di Resource Centre memang difokuskan belajar mendengar dulu, dengan bantuan ABD (Alat Bantu Dengar) anak-anak sedikit terbantu untuk belajar mendengar, tetapi tidak semudah itu untuk bisa dikatakan lancar dalam mendengar hanya dengan memasangkan ABD di anak tersebut, tetapi masih ada tahapan-tahapan khusus yang nantinya bisa membantu meningkatkan kemampuan berbahasa dan berbicara mereka.

3. Pola komunikasi interpersonal antara trainer dengan anak berkebutuhan khusus (anak tuli) di UPT Resource Centre ABK Gresik

Setelah mengetahui proses komunikasi serta metode pembelajaran yang dilakukan para trainer dengan anak tuli bisa dilanjutkan dengan melihat pola komunikasi interpersonal antar trainer dengan anak-anak tuli. Dalam melakukan komunikasi tentunya mengiginkan komunikasi itu berjalan dengan efektif. Adanya feedback atau respon dari anak tuli, saling bertukarnya informasi, balas membalas pesan tentunya akan timbul keefektifan komunikasi, yang mana mempercepat pendekatan sekaligus kelancaran dalam terapi yang dilakukan para trainer dengan anak tuli.

Bisa dilihat pendekatan holistik yang dilakukan trainer atau Novi pada tiap anak tuli yang melakukan terapi, mulai dari yang balita Safirah, M. Hisamudin Zein, M. Rizky A., M. Rafif Izzudin, M. Aditya Naufal A, Alvian, Zulfan Qunurul, Dirga (Alif), Arvin, Hisam, Fatim, dan Thalia Adiva sampai yang diatas lima tahun Aurel, Uyyun, M. Izzan 
Danish, Tristan, dan Pandu. Novi akan memberikan keterbukaan dengan menjemput mereka yang mau mengikuti terapi di depan RC, selanjutnya memberikan kebebasan pada anak yang masih rewel untuk melakukan aktivitas yang membuat kondisi emosionalnya stabil, setelah itu baru bisa dilakukan terapi pada anak-anak tersebut. Lewat kegiatan dengan memberikan perhatian lebih pastinya memiliki effort yang lebih bagus sebab lewat komunikasi interpersonal jadi lebih bisa membangun hubungan yang lebih harmonis layaknya ibu dan anaknya agar proses terapi berjalan lancar.

Untuk perbedaan tata bahasa cenderung ke anak-anak yang usianya sudah diatas lima tahun, yang memang dari awal tidak mendapat alat bantu dengar serta tidak mendapat terapi khusus. Dalam proses komunikasinya, biasanya lewat tulisan rata-rata bahasanya (subjek, objek, predikat) sedikit berbeda dari biasanya karena memang dari awal sudah terstimulasi, sebab dalam pembentukan bahasa pastinya harus bisa mendengar dengan baik. Di RC ini anaknya rata-rata sudah menggunakan alat bantu dengar yang mana bisa memudahkan anak-anak yang mengalami gangguan pendengaran agar bahasa mereka bisa terbentuk secara sempurna.

Pendekatan emosional di RC ini menggunakan metode pendekatan Holistik, yang mana suatu metode pendekatan yang membangun manusia secara keseluruhan dan utuh dengan mengembangkan semua potensi manusia yang mencakup potensi sosial-emosi, potensi intelektual, potensi moral atau karakter, kreatifitas, dan spiritual. Pendekatan ini di RC lebih menekankan pada kebutuhan yang cocok untuk tiap-tiap anak, meliputi pendekatan emosional anak tersebut.

Jadi bisa dikatakan komunikasi interpersonal lebih cocok dengan pengajaran atau terapi yang dilakukan para trainer pada anak yang mengalami gangguan khususnya anak tuli. Nantinya bisa lebih mendekatkan ikatan antara trainer dan anak tuli dan terciptanya kelancaran dalam komunikasi serta proses terapinya.

Anak yang bisa dikatakan tidak balita dan sudah kooperatif dan masih belum menggunakan alat bantu dengar, serta tidak mendapat terapi khusus guna meningkatkan kemampuan berkomunikasinya lewat oral atau mulut dalam berkomunikasinya mereka menggunakan abjad huruf atau nonverbalnya serta menggunakan media tulisan sebag ai cara komunikasi mereka.

Pola komunikasi interpersonal yang terbentuk antara Trainer dengan anak tuli disebabkan karena adanya proses komunikasi yang setiap hari berlangsung antara trainer dengan muridnya. Proses komunikasi selalu dilakukan oleh trainer karena 
memang proses komunikasi merupakan bagian dari proses pembelajaran. Didalam proses pendidikan pun $80 \%$ pasti terjadi komunikasi entah itu verbal atau pun non-verbal.

Berdasarkan hasil penyajian data yang diperoleh oleh peneliti di lapangan dapat disimpulkan bahwa pola komunikasi yang terbentuk antara Trainer dengan anak tuli adalah pola komunikasi Sirkular dan juga Primer. Pola sirkular ini penggambarannya atau alur komunikasinya secara sirkular yang berarti bahwa komunikasi disini dapat saling mengirimkan pesan kemudian diterjemahkan atau diinterpretasikan yang selanjutnya dapat diteruskan dengan umpan balik kepada pengirim pesan dan juga berlangsung secara simultan. Pola komunikasi primer ini merupakan suatu proses penyampaian oleh komunikator kepada komunikan dengan menggunakan suatu simbol sebagai media atau saluran. Dalam pola ini terbagi menjadi dua lambang, yaitu lambang verbal dan nonverbal.

\section{Guna}

meningkatkan

kemampuan berkomunikasi (berbahasa dan berbicara) anak-anak tuli, peneliti ingin memaparkan hasil dari pengumpulan data terkait metode pembelajaran seperti apa yang dilakukan para trainer di Resource Centre ini. Ada bentuk atau model pembelajaran yang digunakan di Resource Centre yakni berbagai macam terapi seperti terapi fisiologis, terapi belajar, terapi autis, dan terapi wicara. Disini peneliti lebih menelisik lebih jauh mengenai terapi wicara sebab terapi wicara adalah terapi bagi ABK bagi anak yang mengalami kelambatan, kesulitan bicara, atau kesulitan berkomunikasi. Terapi ini dilakukan dengan mengajarkan atau memperbaiki kemampuan agar anak dapat berkomunikasi secara verbal yang baik dan fungsional sehingga kemampuan anak dalam berkomunikasi dapat meningkat lebih baik.

\section{Kesimpulan}

Dalam proses awal komunikasinya yang terjadi saat terapi berlangsung antara trainer dengan anak tuli, pertama-tama para trainer melakukan pendekatan emosional anak secara holistik. Dimana menyesuaikan dengan kebutuhan atau kondisi anak itu sendiri sebab tiap anak memiliki karakter serta intelejensi yang berbeda-beda.

Guna meningkatkan kemampuan berbahasa dan berbicara terapi yang dilakukan di RC yakni terapi wicara, bentuk pengajarannya sendiri dengan menggunakan Audio Verbal Teraphy. Adapun faktor penunjang yakni pada teknologi yaitu Alat Bantu Dengar. Kemudian penghambatnya sendiri bisa juga pada ABDnya yang kurang cocok.

Pola komunikasi yang terjadi dalam proses terapi guna meningkatkan kemampuan berkomunikasi anak tuli di 
Resource Centre yakni pola komunikasi sirkular dan juga primer.

\section{Daftar Pustaka}

Departemen Pendidikan Nasional. "Kamus Besar Bahasa Indonesia edisi ke-3". Jakarta: Balai Pustaka, 2002.

Departemen Pendidikan Nasional. Kamus Besar Bahasa Indonesia. Jakarta: New Phoenix, 2002.

Guntur, Henry Tarigan. Berbicara Sebagai Suatu ketrampilan Berbahas. Bandung: Angkasa, 1983.

Lestari, Kathartika. "Pola Komunikasi Efektif Trainer Pada Training Induction Karyawan Btpn Syariah". Thesis: UNPAS Yogyakarta: 2017.

Mafazi, David. Kompetensi Seorang Trainer. Akses November 2, 2019. https://warstek.com/2018/05/23/traine r/.

Megawangi, Ratna. Pendidikan Holistik. Cimanggis: Indonesia Heritage Foundation, 2005.

Pramudyo, Chrisogonus D. Cara Pinter Jadi Trainer. Indonesia Cerdas: Yogyakarta, 2007,

Somad, Permanarian. Ortopedagogik Anak Tunarungu. Bandung: Departemen Pendidikan dan Kebudayaan, 1995.

Somad, Permanarian. Ortopedagogik anak Tunarungu. Bandung: Departemen Pendidikan dan Kebudayaan, 1995.

Sunardi. Intervensi Dini Anak

Berkebutuhan Khusus. Jakarta: Departemen Pendidikan dan Kebudayaan, 2007.
Suranto, Aw. Komunikasi Interpersonal. Yogyakarta: Graha Ilmu, 2011.

Syah, Muhibbib. Psikologi Belajar. Jakarta: PT Raja Grafindo Persada, 2007.

Uchjana, Onong Effendy. "Dinamika Komunikasi”. Bandung: PT. Remaja Rosdakarya, 1993. 